\title{
Conclusion
}

\section{Between the Last Financial Crisis and the Next One}

The financial crisis of 2008 is now receding from view. It is no longer in the daily newspaper headlines. Although the economic consequencesparticularly for the distribution of wealth-are very much still with us, public attention seems to be elsewhere. In the United States, the Trump administration and Congress are pushing for a substantial repeal of the DoddFrank regulations put in place to try to prevent or at least lessen the impact of the next financial crisis.

Nevertheless, another financial crisis is on the horizon. We know this, although we are unsure about the precise details of the timing or the origin of the contagion. And we know this in spite of the policymakers' models, which still assume that financial crises are extraordinary or unlikely events.

As with the crisis of 2008, the impact will most likely be global and pervasive. Ordinary citizens will pay a heavy price, just as they did in 2008. Retirement savings accounts will experience losses. Homes will be worth less than before. Jobs will be at risk. Many workers may be forced, once 
again, to endure cuts to wages or benefits. In the developing world, the consequences may be more extreme.

When the next financial crisis occurs, governments will once again have to face a choice: Should taxpayer funds be used to bail out financial institutions? Should central banks once again inject large amounts of cash into the economy through the banks? Should central banks purchase the assets and debts of private companies to keep them afloat? These are not just technical questions but normative questions. As David Archer, head of Central Bank Studies at the Bank for International Settlements, argues, such choices also precipitate a "coming crisis of legitimacy": "Central banks are showing a strong inclination to use powers that they already have, or could be argued to have, for new, imperfectly-defined purposes. It is this reinterpretation of the proper use of delegated state powers that threatens legitimacy."

As Peter Katzenstein has suggested, the next crisis will be far more politically complex than the last one. The speed and velocity of contemporary politics is simply much greater than it was then. Having developed a narrative of popular outrage against elites, the public will not accept backroom bailouts and technical talk of swap lines as being in the public interest as easily as it did in 2008. Moreover, the changing nature of the media itself-in particular the rise of alternative and social media that are far more difficult for policymakers to manage_-assures that the public backlash will be faster and stronger.

Given all of this, now is the time to address the legitimacy of central bank actions, the tools to be used, and the choices to be made. We must do this before the next crisis hits, through democratic processes, rather than allowing our collective response to be relegated to rushed decisions by elites behind closed doors in the panic of the moment. This is as urgent a macroprudential matter as any other on the agenda of central banks today.

In the United States, the regulatory framework introduced through Dodd-Frank was designed to prevent market participants from taking on too much risk or from cheating borrowers and investors. It was meant to force market participants to put aside enough assets to protect them in the event of a crisis, as well as to allow regulators to gather information about problems in advance so that they can hopefully be addressed before a calamity occurs. A second goal of the Dodd-Frank legislation was to ensure that the industry would create its own insurance system. It was designed to 
force the banks to set aside funds so that in the event of a systemic instability or failure, these funds could be used to resolve the situation without having to dip into tax coffers.

The approach of Congress was to do everything possible now to lessen the possibility of a financial crisis in the future. Or if a crisis cannot be averted, Congress hoped to reduce the cost to taxpayers by asking banks to change their practices now. So here is an example of a point at which the public has a political decision to make: changes to Dodd-Frank will have profound consequences on all of us when the next financial crisis occurs.

Financial governance involves trade-offs: benefits for some and costs for others. That makes it highly relevant to ordinary people's daily lives. The public has a right, as well as a duty, to join the conversation.

It is, of course, difficult for central banks to communicate honestly and fully with the public or the market about the possibility of crisis in advance. The fear is that any suggestion that there is even a chance of crisis will lead to an exaggerated market response that could, in fact, precipitate the kind of market downturn it seeks to avoid. Yet it is precisely this difficult, complex conversation about unknowns, second-best options, and trade-offs that desperately needs to occur among policymakers, scholars, and the public. And it must happen now.

This conversation will require more than just policy change; it will require a paradigm shift. It will require new academic approaches, new research questions, and new policy tools. Even more than this, it will require a new kind of conversation between the experts and the public. Central bankers must now embrace a new collaborative relationship with the public because they cannot avoid it, and because they also cannot abdicate the authority to do it as long as elected officials have delegated to them responsibility and authority for the economy. In practice, this means acknowledging the possible limitations and blind spots in one's own worldview. And it means working as hard as possible to bring other constituencies-especially the global public - into the decision-making process.

Much has been made of the question of how central bankers are appointed, how long their terms should be, and what kinds of reporting requirements to elected officials are necessary to confer legitimacy on central banks' actions. These are important questions, but legislative oversight cannot in itself absolve central bankers of responsibility for engaging with the public, just as deference to the legislature or pure transparency regarding 
all central bank decisions may not be in the best interest of the public at large.

Rather, recognition that central banking is cultural, in the complex and sophisticated sense articulated here, confers on policymakers, scholars, and members of the public a responsibility to continue to communicate and to collaborate in the care for the resilience of the market, just as they would do with any important democratic institution.

Members of the public too must assume responsibility for bringing about a new kind of politics of central banking. There are many opportunities to do this. Central banks are increasingly subject to legislative oversight. Elected officials are demanding more regular briefings from central bankers and are asking for greater involvement in setting targets — and perhaps even the means of achieving those targets. One implication is that central bankers are increasingly called on to speak to the public about what they are doing. When the governor of the Bank of Japan or the chairman of the Federal Reserve testifies before the legislature, they make statements that are reported in the news media, and they are asked questions from politicians that are shaped by input from constituents and interest groups.

These briefings are opportunities for the public to engage the financial governance experts. The rise of social media and new information technologies has significantly reduced the barriers to contact with elected officials through these events. Taking advantage of this, a number of citizens' advocacy organizations have emerged since the financial crisis to counter the impact of the large financial institutions and give voice to ordinary citizens. Central bankers and regulators are highly sensitive to the responses that they receive from these encounters with the public and with legislators because the success of their interventions turns on their credibility. Many central bankers are in fact eager to engage more with the public, but lack a vehicle to do so. We can also invite central bankers to engage with our own organizations, just as they often attend meetings sponsored by the financial industry. In this way we can create opportunities for both sides to learn about one another's worldview. We can follow what central banks do in the media and engage with these policies from the point of view of on-the-ground economic and political realities through social media and the mainstream media.

A focus on cultural conflicts between experts and publics is not a panacea, of course. On the contrary, cultural analysis is by definition difficult, 
personal, ambiguous, and open-ended. Cultural conflicts are frustrating. Thus, one criticism of the perspective adopted in this book is that a serious engagement with cultural difference is too much to ask either of our government officials or of the public.

My response is, first, that whether we recognize it explicitly or not, we are already engaged in acts of cultural conflict - acts that have serious and lasting political and moral consequences. The issue then is, should this remain an unselfconscious, ad hoc, largely amateuristic, and arguably hegemonic exercise? Or should we confront our choices and our descriptions head on and struggle with the frustrating but ultimately important task of making our engagements in cultural conflict as sophisticated and principled as we can? The contention of this book, in other words, is that at least these are the right frustrations to have. I view this as a proposal to recognize what many central bankers are already doing, and in some areas to push to do more of this, rather than a proposal to do things entirely differently.

A second likely criticism of this proposal will come from two camps that at first blush might seem radically opposed. On the one hand, advocates of the status quo will regard my views of the expert's cultural responsibilities as far too accommodationist of popular values and concerns, and possibly even for this reason as lawless. From the opposite camp, on the other hand, the representatives of populist groups on both the right and the left may be distrustful of the possibility of honest dialogue.

I respectfully acknowledge the basis and legitimacy of these fears. Indeed, it is the fact of these fears, the fact of the "danger" of dialogue, that makes financial citizenship in conditions of culture clash so important. As the cultural theorist Ghassan Hage says, hope without fear is no hope at all. Real hope, he argues, requires that something be wagered, something be truly risked. ${ }^{2}$

Of course, the challenge is by no means unique to central banks. The shift to a more subtle and sophisticated relationship between experts and publics advocated here is necessary across the wider economy, the sciences, and society. How we manage this paradigm shift has profound implications not just for our economies, but for our democratic institutions as well. 
